\title{
Exploration of Environmental Care Attitudes in Students Ar-Rohmah Islamic Boarding School Malang Based on the New Ecological Paradigm Instrument
}

\section{Dewi Arif Hidayati, *H. Husamah, Diani Fatmawati, Fuad Jaya Miharja, Ahmad Fauzi}

\author{
Program Studi Pendidikan Biologi FKIP Universitas Muhammadiyah Malang; Jl. Tlogomas 246 \\ Malang, Indonesia 65144 \\ *Corresponding Author e-mail: husamahumm@gmail.com
}

Received: September 2020; Revised: October 2020; Published: November 2020

\begin{abstract}
This study aimed to determine the attitude of concern for the environment among the students at Pondok Pesantren Ar-Rohmah Malang. This research was an ex post facto research where the researcher reveals and describes the facts about the environmental care attitude of the students at ArRohmah Islamic Boarding School Malang. The population in this study were all students of ArRohmah Senior High School Malang. The sample in this study were students of class 10, 11, and 12 SMA Senior High School Ar-Rohmah Malang who were randomly selected with the number of students in each class as many as 35 students and total as many as 210 students. The results showed that in general, the students of Ar-Rohmah Senior High School Malang tend environmental care / proenvironmental attitudes rather than social paradigm attitudes. Class differences indicate a difference in the percentage of caring attitudes towards the environment. If we look at each item, based on the percentage of responses to the NEP instrument, the students of AR-Rohmah Senior High School Malang is not understood holistically on several materials such as the balance of ecosystems, the right of natural resources not to be exploited continuously, and the obligation of humans to protect the environment and cultivate it wisely.
\end{abstract}

Keywords: environmental care; NEP instruments, islamic boarding school

How to Cite: Hidayati, D., A., Husamah, H., Fatmawati, D., Miharja, F., J., \& Fauzi, A. (2020). Exploration of Environmental Care Attitudes in Students Ar-Rohmah Islamic Boarding School Malang Based on the New Ecological Paradigm Instrument. Jurnal Penelitian dan Pengkajian Ilmu Pendidikan: e-Saintika, 4(3). doi:https://doi.org/10.36312/e-saintika.v4i3.277

https:// doi.org/10.36312/e-saintika.v4i3.277

Copyright $\odot$ 2020, Hidayati et al This is an open-access article under the CC-BY-SA License.

\section{INTRODUCTION}

Environmental literacy is an individual's knowledge and understanding of the concepts and principles that occur in the environment (Maknun, 2011). The planting of environmental concepts and principles can be applied by preserving the environment. Environmental literacy can equip people with a conscious and loving attitude to protect the environment to maintain its balance and the existence of abundant natural resources. (Kusumaningrum, 2018; Nasution, 2016). Children's responsiveness and sensitivity to the environment can develop with environmental education, as conveyed byKomariah et al. (2017); Farwati et al. (2018); Elvazia (2017). The existence of environmental literacy education for students can build an 
understanding of the main concepts regarding ecological phenomena and problems so that a sense of responsiveness and sensitivity to the environment emerges. With the many interests in environmental literacy, it is hoped that the ability of environmental literacy to be taught to the community is more primarily instilled in students through environmental education so that environmental literacy characters are formed.

Environmental education has been learned since elementary school through learning material contained in science subjects. Meanwhile, the habit of loving the environment is stated in the slogan in the environmental area as well as direct education from the teacher. Critical thinking and a caring attitude are needed in finding solutions to environmental problems. This is following the opinion from Desfandi (2015); Farwati et al. (2018); Zulfa et al. (2015) The environmental learning process for students should emphasize the concept of the environment so that it can equip students with a caring attitude towards the environment and the ability to think critically to solve all environmental problems. Mulyana (2009) stated that the learning process in the school environment aims to make students have a provision for environmental literacy to create a beautiful and comfortable school environment. On a broader scale, Home (2020) stated that the objective of environmental education as stated in the Tbilisi charter is to produce citizens who are knowledgeable about the environment so that they can provide the best solutions to environmental problems. Citizens include students.

The majority of students in Indonesia currently have low environmental literacy skills, this is due to the lack of interest in students to explore their knowledge of the environment and low concern for the environment. The above statement is following the opinion Nasution (2016); Apriliani (2019); Amini and Munandar (2010), stated that the level of literacy of students is very low, this is due to the low curiosity to learn about environmental problems and a caring attitude towards the environment. This is supported by the Progress International Reading Literacy Study (PIRLS) data in 2011 which states that the results of the Indonesian literacy test rank 45th out of 48 participating countries (Mullis et al., 2012). Although Natural Sciences (IPA) subjects have been taught, they are not yet fully able to equip students with knowledge and attitudes to care for the environment. Said Widianingsih et al (2017) that the implementation of environmental education in schools in Indonesia is not yet fully effective which causes low environmental literacy skills in students. This happens because, in the use and implementation of the syllabus, lesson plans, and worksheets have not been able to facilitate environmental literacy learning (Widianingsih et al., 2017). Previous research that has been conducted by Pujianti (2018) argues that students' environmental literacy is low due to the low intention of students to know and study environmental problems.

If we look at literacy broadly in the Islamic boarding school area, it turns out that there are still many Islamic boarding schools that have not implemented environmental education. This is following the opinion Nisa (2019) environmental education has been widely applied in several Adiwiyata schools, but in the pesantren environment, there is not much teaching. Environmental education for students in Islamic boarding schools is very important because they live 24 hours in that environment so that the surrounding environment needs to be kept clean. Also confirmed by Muhith (2019) the reality is that the majority of pesantren graduates still have not mastered literacy skills, especially in reading skills. 
Environmental literacy according to McBeth and Volk (2010) consists of 4 components, namely: knowledge, attitudes, behavior, and cognitive skills. The component of attitudes towards the environment in environmental literacy includes statements of attitudes to care for the environment. This component of attitude towards the environment is very important for students. According to Kusumaningrum (2018), someone is considered to have environmental literacy if not only knows the environment but also has a responsive attitude and can provide solutions to environmental issues.

Several instruments can be used to measure environmental literacy. However, one instrument that focuses on measuring environmental awareness is the New Ecological Paradigm instrument (NEP). According to Dunlap et al. (2000), the NEP instrument is a reliable instrument to be used as a measure of one's concern for the environment. The NEP instrument has also become an instrument that has been popularly used as a tool to measure environmental awareness and reflect a proenvironmental orientation. According to (Nugroho et al., 2016) the NEP scale is proven to be consistent as a measuring tool and has been tested in various studies measuring pro-environmental and anti-environmental attitudes and behavior in various countries. The NEP instrument developed by Dunlap et al. (2000) is the result of a revision of the New Environmental Paradigm Scale developed by Dunlap and Van Liere (1978) with a total of 12 items. Over time, environmental problems have become more complex so that the New Ecological Paradigm Scale needs to be revised to adjust to changes in existing environmental problems by adding several items to become 15 items. According to Dunlap et al. (2000) and Martini (2019) revisions of the NEP include a more complete key view and use newer terms. The revised NEP scale maximizes content validity as a measure.

Ar-Rohmah is an Islamic boarding school-based educational institution. The function of education in Islamic boarding schools does not stop as a knowledge transfer activity but as a guardian of Islamic values (Syafe'i, 2015). Islam as a religion not only regulates the relationship between humans and their Rabb, but also regulates human relations with environmental sustainability (Hidayat, 2015). Besides, the Ar-Rohmah Islamic Boarding School has a unique curriculum, namely the Khas Hidayatullah Nursing Curriculum. The implementation of the curriculum is that students have an empathetic character for the environment (Ar-Rohmah Putri, 2019). One of the successes of the curriculum application can be measured by environmental literacy.

This study aims to explore the environmental care attitude of the students at ArRohmah Islamic Bording School Malang based on the New Ecological Paradigm (NEP) instrument. The existence of research on the exploration of environmental care attitudes towards students at Ar-Rohmah Islamic Bording School Malang is expected to be one of the foundations / references in implementing environmental education in schools, especially in Islamic boarding schools. In addition, the results of this study can later be used as material for the teacher's consideration to initiate and improve the learning environment for students.

\section{METHOD}

The type of research used in this research is ex post facto research where the researcher reveals and describes the facts about the environmental care attitude of the students at Ar-Rohmah Islamic Bording School Malang. The number of 
respondents involved in this study was 105 students of Ar-Rohmah Putri High School and 105 Ar-Rohmah Putra High School students. This research was conducted at Ar-Rohmah Putri Islamic Boarding School Malang, which is located at Jalan Jambu No. 1 Semanding Dau Malang and in Ar-Rohmah Putra Islamic Boarding School Malang, which is located at Jalan Apel No. 61 Semanding Dau at the Malang Regency. This research was conducted in July - September 2020.

The design of this study was a randomly selected sample of students in grades 10, 11, and 12 with 35 students in each class. Then the students were asked to fill in an instrument to measure environmental awareness. As for supporting data, researchers conducted interviews with several teachers and observations around the pesantren environment. The instrument used to measure attitudes of caring for the environment in this study was the New Ecological Paradigm (NEP) instrument developed by (Dunlap et al., 2000). This NEP instrument consists of 15 statement items which are divided into 5 dimensions, namely: Anti-exemtionalism, Antianthropocentrism, Limits to growth, Balance of nature, Eco-centric. In its measurement, this instrument uses 5 linked scales, namely strongly agree, agree, not believe, disagree and strongly disagree. The NEP instrument developed by Dunlap et al. (2000) is the result of a revision of the New Environmental Paradigm Scale developed by Dunlap and Van Liere (1978) with a total of 12 items. The data analysis used in this study is, for quantitative data in the form of the response results of the NEP instrument, it was carried out by using descriptive statistical data analysis techniques. Meanwhile, quantitative data in the form of interviews and observations were analyzed using content analysis developed by (Miles, 1992).

\section{RESULTS AND DISCUSSION}

The results obtained from this study were the percentage of responses to the NEP instrument by students of SMA Ar-Rohmah Malang. The following was a graph of the percentage of responses to the NEP (New Ecological Paradigm) instrument for students of Ar-Rohmah Senior High School Malang grades 10, 11, and 12 (Figure 1, Figure 2, \& Figure 3).

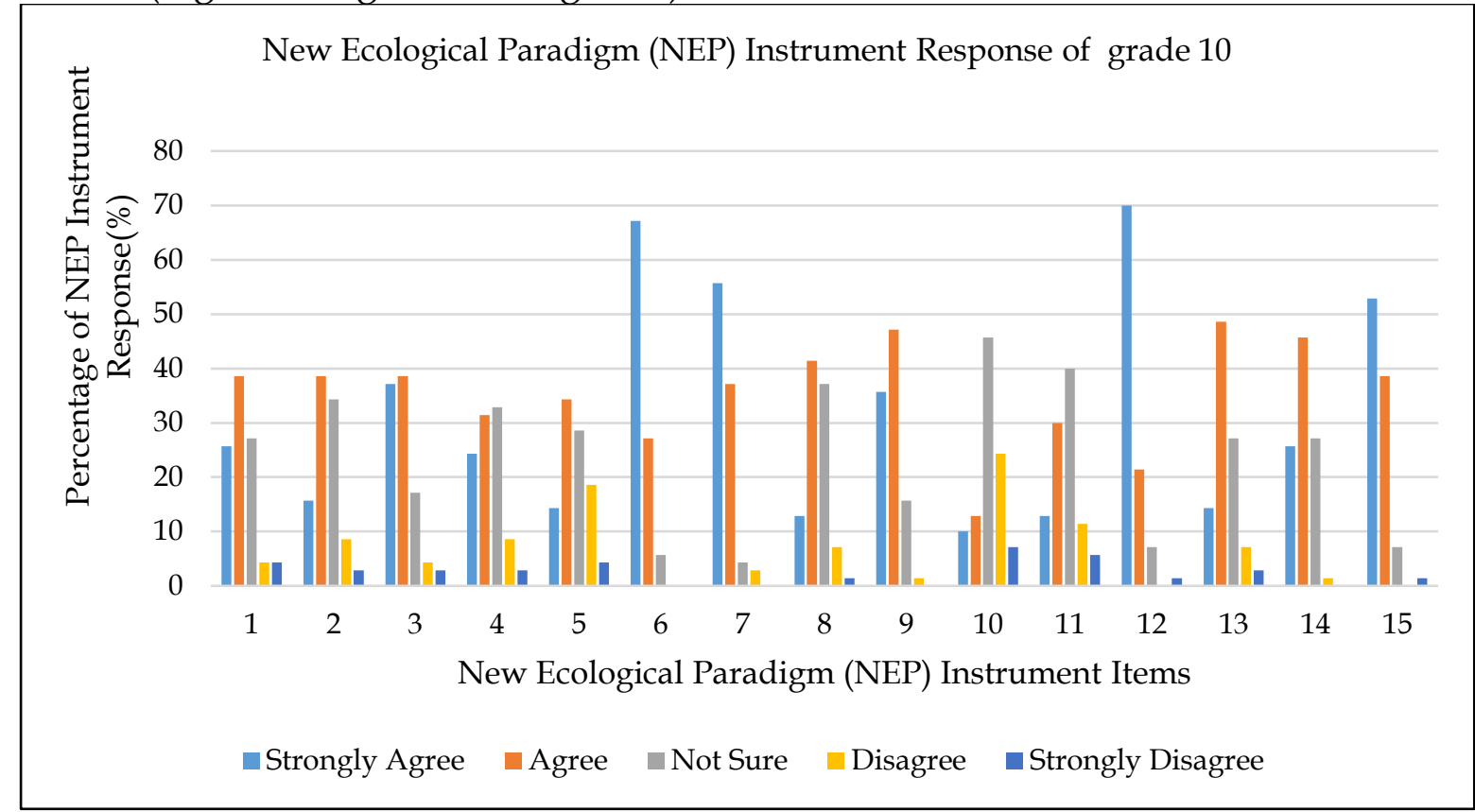

Figure 1. Graph of the percentage response to the Class 10 NEP (New Ecological Paradigm) instrument 


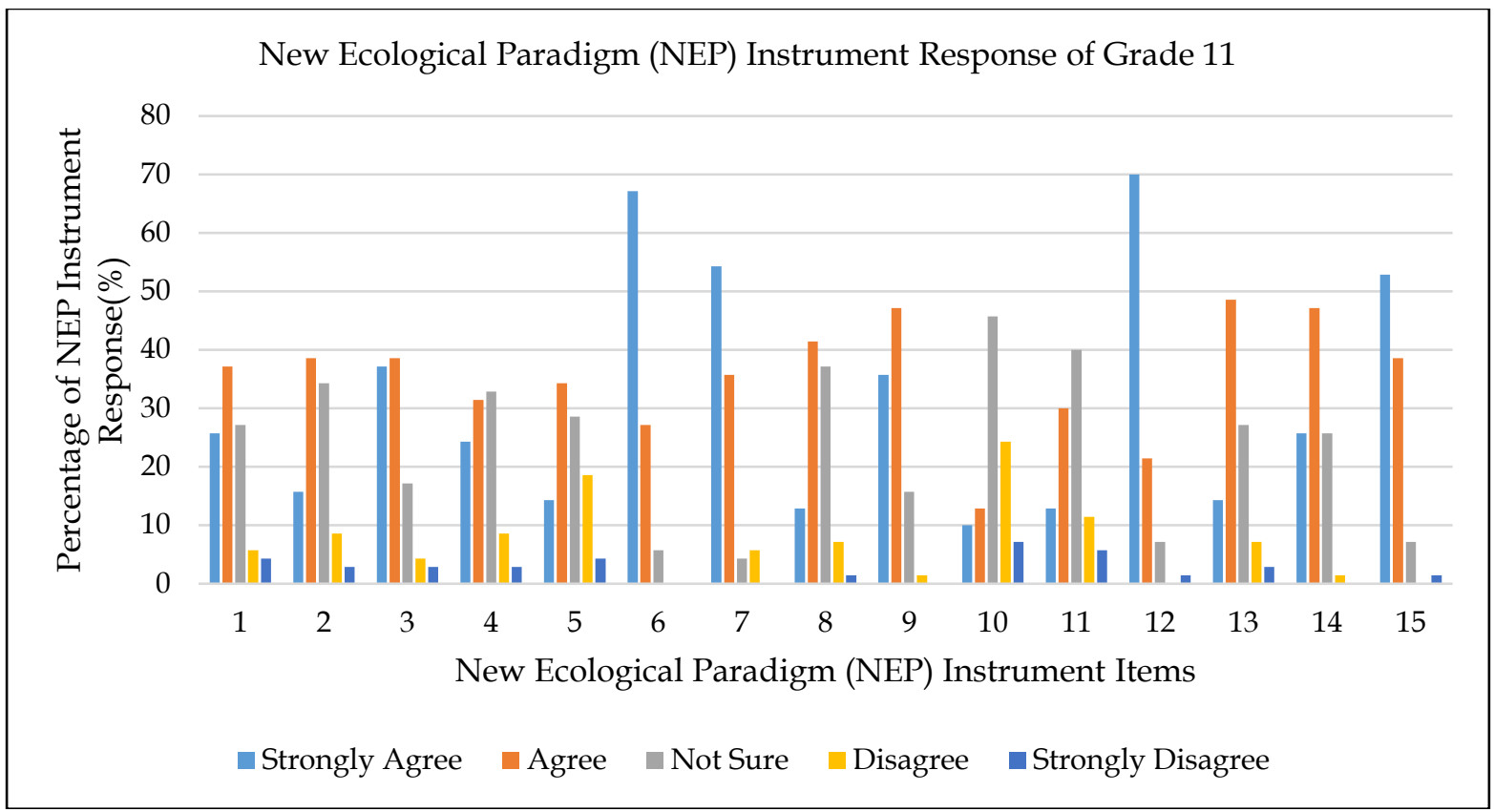

Figure 2. Graph of the percentage response to the NEP (New Ecological Paradigm) class 11 instrument

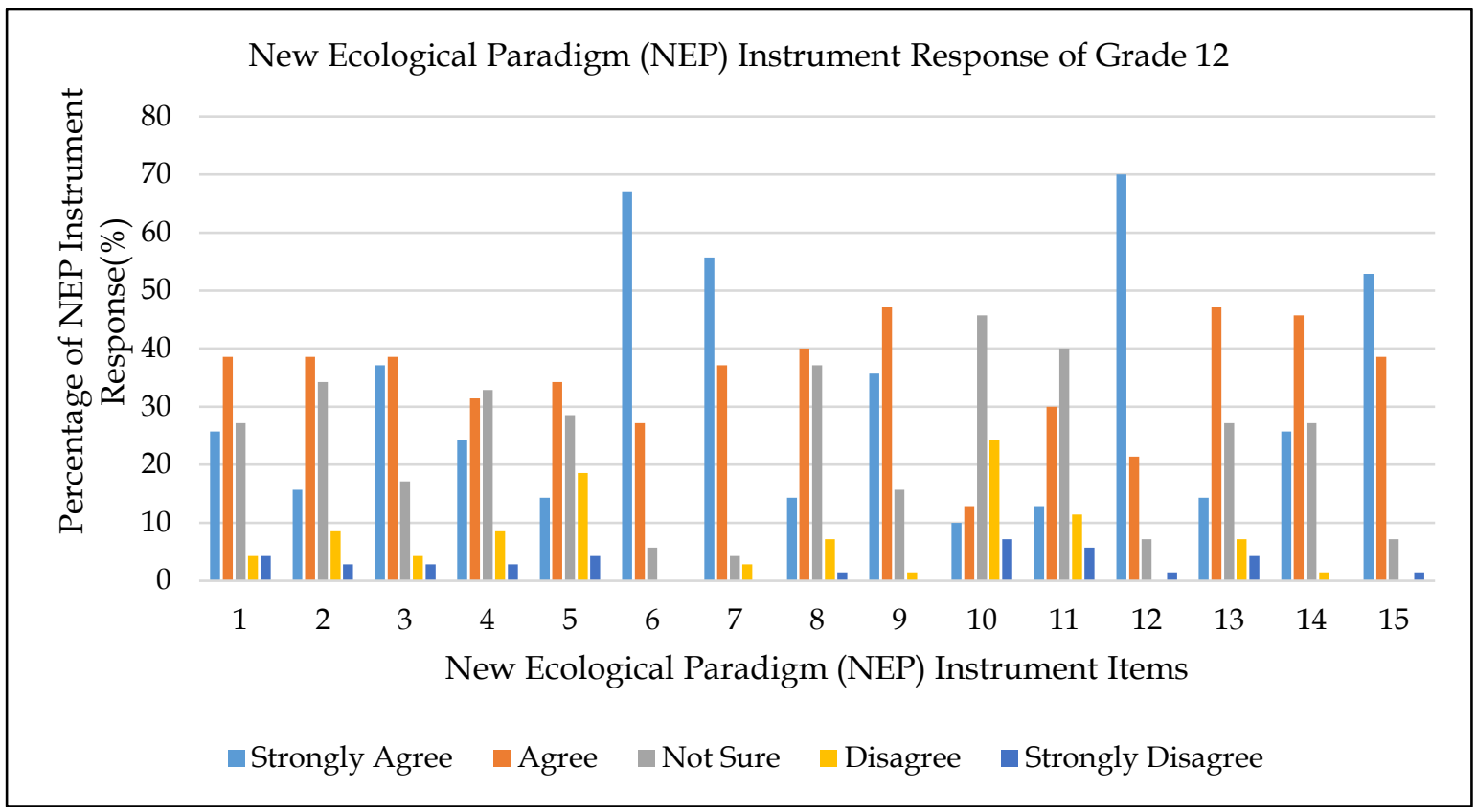

Figure 3. Graph of the percentage response to the class 12 NEP (New Ecological Paradigm) instrument

Based on graphs on Figure 1, Figure 2, and Figure 3, it was found that most of the respondents chose a positive response (strongly agree and agree with options) on all items of the NEP instrument. However, not a few respondents who chose the option were not sure. Only a small proportion of respondents chose a negative response (options disagree and strongly disagree).

If grouped by odd and even items, the following was a graph of the percentage of agreed responses on the NEP instrument (Figure 4 \& Figure 5). 


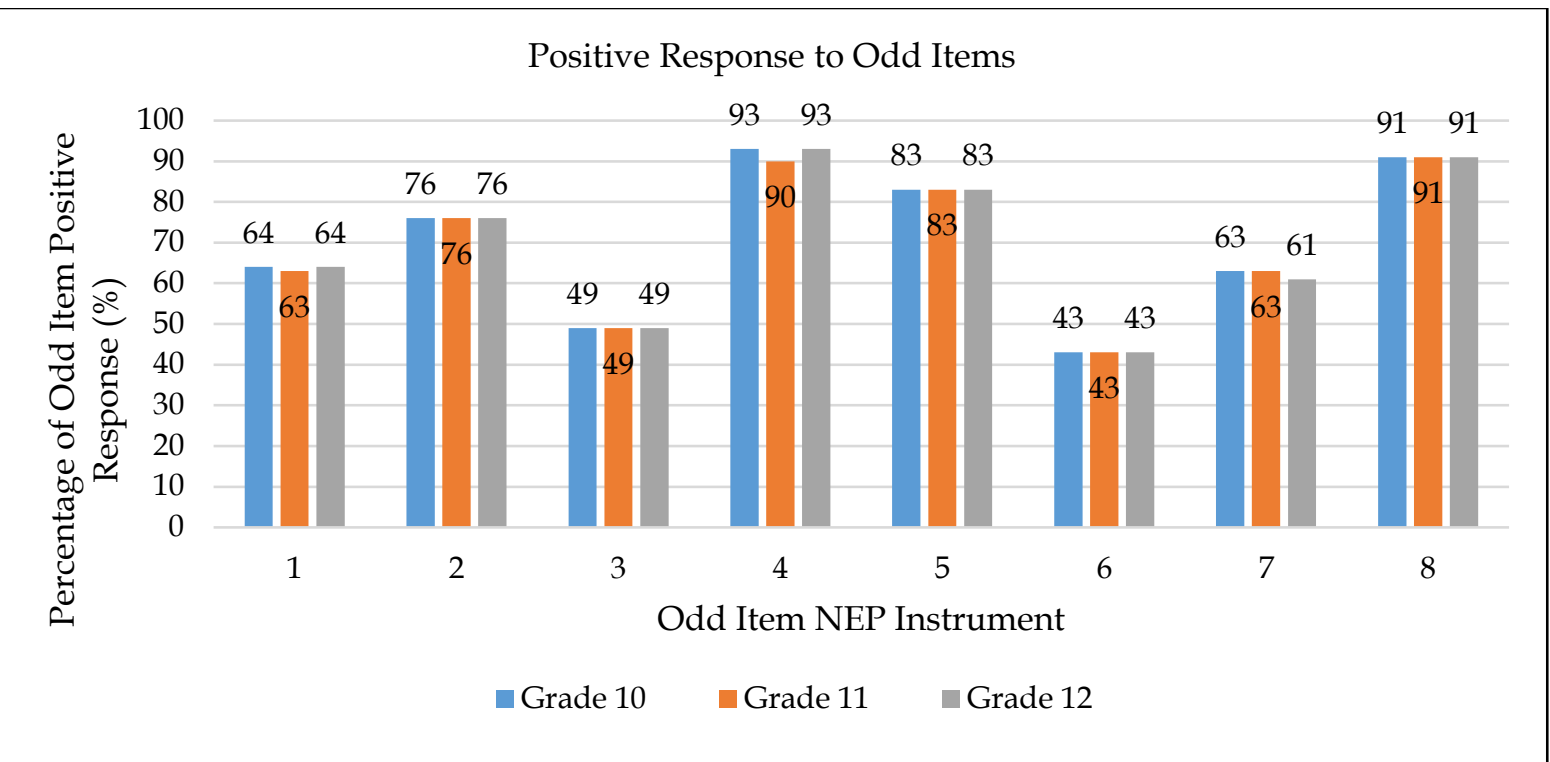

Figure 4 . The response graph agrees with the odd-numbered NEP instrumen

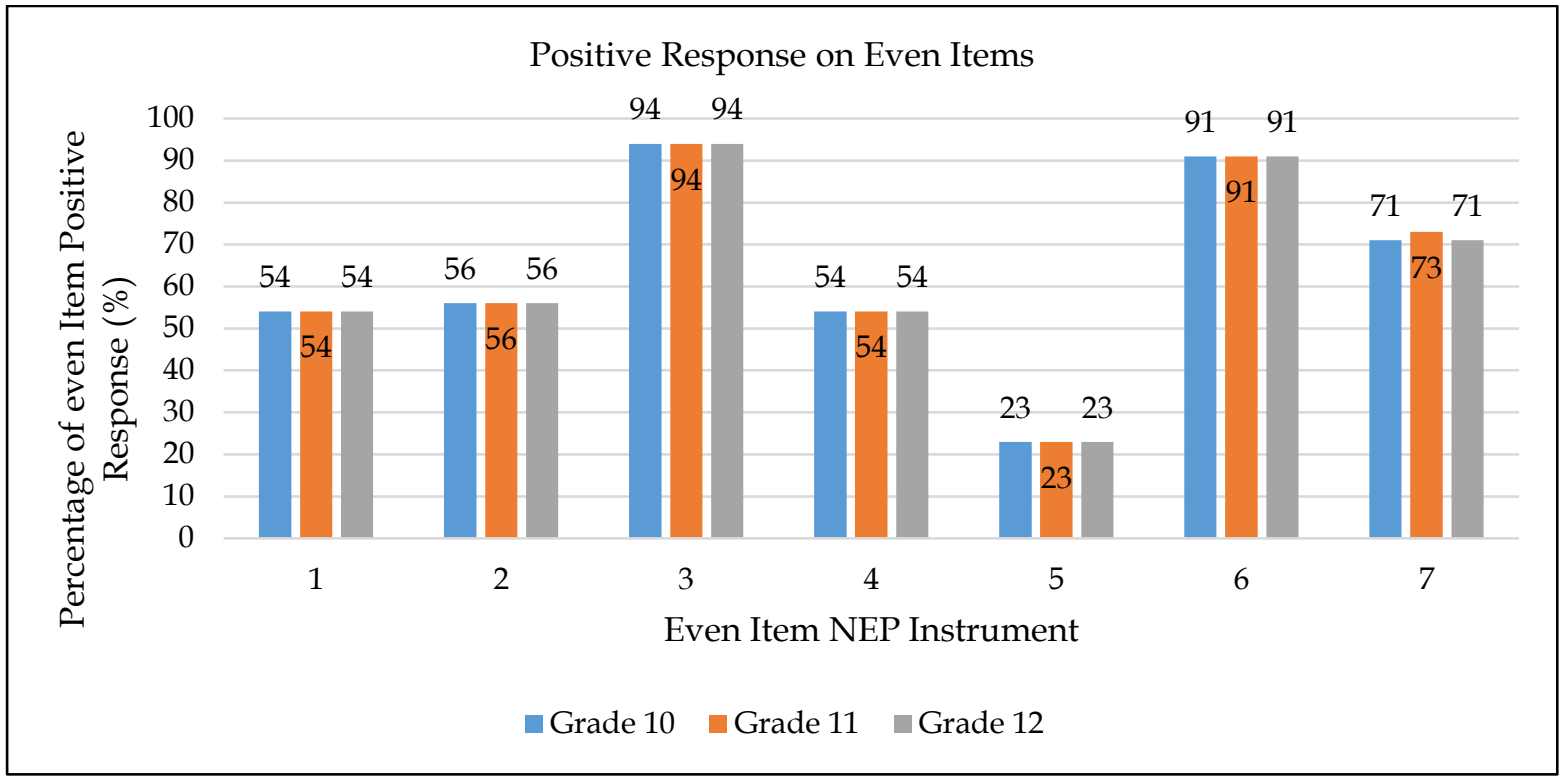

Figure 5. The response graph agrees that the NEP instrument is even-numbered

In Figure 4 and Figure 5, information was obtained that about $70 \%$ of respondents chose a positive response (strongly agree and agree with options) on odd items. However, not a few respondents also chose a positive response (strongly agree and agree with options) on even items, around $63 \%$.

Based on the results of the analysis, $70 \%$ of all respondents chose a positive response (both options strongly agree and agree) on odd items. According to to Lawton (2016), Each odd-numbered statement item on the NEP instrument that answered positively reflects a positive attitude towards the environment. However, not a few respondents (about 63\%) answered positively (both strongly agree and agree) on the even-numbered item statement. The even numbers on the NEP instrument represent the social paradigm. According to Lawton (2016), If the respondent gave a positive answer to the even number statement it reflects a more dominant attitude towards the social paradigm and were not agree with the new ecological paradigm or was not pro-environmental. The description above showed that the students of SMA Ar-Rohmah Malang tend towards a pro-environmental 
attitude even though the difference with the pro-social paradigm was not so significant.

The similarity in positive responses to odd and even items could be caused because respondents who filled out the NEP instrument were high school students. This could be possible because high school children did not have a complete understanding so that their analytical skills in translating the meaning of each item of the NEP instrument were still not perfect. So that on certain items that were more supportive of the social paradigm, respondents also choose a positive scale. Therefore the results obtained were not much different between pro-NEP and those who support the social paradigm. According to Ibda (2015)based on Piaget's cognitive development theory, children aged 12 years and over are in a formal operational stage where they were developing conceptual thinking and hypothetical thinking. However, according to Saputro (2018) Emotionally, middle adolescence still tends to experience confusion and anxiety in decided something. This was also related to the number of respondents who chose the unsure option, indicating that not a few respondents still had doubts about determining positive and negative answers.

When viewed based on differences in grade levels, showed a difference in positive responses on the odd NEP item. The percentage of positive responses to odd items in class 10 was $70.25 \%$. While the percentage of agreed responses to odd items in class 11 was $69.75 \%$ and class 12 was $70 \%$. This figure shows that age differences affect a person's attitude towards the environment. According to Ibda (2015) that apart from age, the level of knowledge and the stages of intellectual development greatly affect the individual's ability to observe science (way of thinking). This means that because the level of knowledge and knowledge obtained at each class level was different, so their way of thinking was also different. However, based on the data obtained, the results from grade 10 were higher than in grade 11 and grade 12. This could be caused by several factors, including parenting styles and teacher learning strategies in class. According to Budiningsih (2015), there was a relationship between the learning strategies used by the teacher and the characteristics of students in the form of analytical abilities. According to Anggraini et al. (2018), A person's personality would affect their morals, morals, character, ethics, and aesthetics. One of the factors that influence personality was the parenting style of parents and their family environment.

When viewed from each item statement of the NEP instrument, the average percentage value in item 1 is $64 \%$. This means that more than half of the respondents agreed that the number of people today was approaching the maximum limit that could be tolerated by the earth. So that most of the students of Ar-Rohmah Senior High School had an understanding that the earth's population was currently very dense and was almost close to the earth's tolerance limit. This was by the opinion from Puspita et al. (2016), There was a correlation between population and environmental quality degradation. One of the relationships between the decline in the quality of the environment and humans was that most of the decline in the quality of the environment results from human actions/behavior. The mean percentage value for item 2 is $54 \%$. This means that half of the respondents agree that humans have the right to modify the environment to meet their needs. So that most students of Ar-Rohmah Senior High School had an understanding that humans have the right to modify the earth based on satisfied human needs. This contradicts 
the opinion of Taufiq (2016) that the harmony of life between humans and the environment can be maintained properly if there was awareness from humans themselves as leaders on earth to protect and care for the environment as a place where humans were located.

The mean percentage value for item 3 is $76 \%$. This means that more than half of the respondents agreed that when humans change nature, it often caused negative impacts. So that most of the students of Ar-Rohmah Senior High School had an understanding that human activities to modify the environment have a very negative impact. This was following the opinion from Puspita et al. (2016) One of the relationships between the decline in the quality of the environment and humans is that most of the decline in the quality of the environment results from human actions/behavior. The mean percentage value in item 4 is $56 \%$. This means that half of the respondents agree that human intelligence will ensure that the world can be managed so that humans can live in it. So that most of the Ar-Rohmah Senior High School students had an understanding that humans could managed the earth with the intelligence they had so that humans can live in it. This contradicts the opinion of Taufiq (2016) that the harmony of life between humans and the environment could be maintained properly if there was awareness from humans as leaders on earth to protect and care for the environment as a place where humans were located.

The mean percentage value in item 5 is $49 \%$. This means that half the number of respondents did not agree that humans very much abused the environment. So that most students of Ar-Rohmah Senior High School had an understood that human activities did not damage the environment. This contradicts the opinion Adack (2013) that most of the damage to nature and the environment came from human activities such as mining, industry, and exploitation of natural resources. The mean percentage value in item 6 is $94 \%$. This means that nearly all of the respondents agreed that the earth had many natural resources if humans knew how to develop them. So that most of the students of Ar-Rohmah Senior High School had an understanding that the earth has many natural resources that could be utilized with the knowledge possessed by humans. This contradicts the opinion of Taufiq (2016) that the harmony of life between humans and the environment could be maintained properly if there was awareness from humans themselves as leaders on earth to protect and care for the environment as a place where humans were located. According to Subramanian (2018), Natural resources had decreased in quality and quantity due to overexploitation to meet the needs of the growing population.

The mean percentage value in item 7 is $92 \%$. This means that almost all of the respondents agreed that plants and animals had the same rights as humans to live. So that most of Ar-Rohmah Senior High School students have an understanding that plants and animals have the right to live the same as humans. This was following the opinion Liuw (2015) that in providing equal protection to the rights of every person and all animals as flora and fauna to had the right to live which could be protected by law. The mean percentage value in item 8 is $54 \%$. This means that half of the respondents agreed that the environmental balance was sufficient to cope with technological advances. So that most of the students of Ar-Rohmah Senior High School have an understanding that the current environmental balance can be used to overcome the impact of technological advances, for example, was the industrial revolution. However, according to Sukwika et al. (2018), environmental damage was 
precisely due to technological advances such as the exploitation of natural resources for accelerated growth in economic development.

The mean percentage value for item 9 is $83 \%$. This means that more than half of the respondents agreed that even though humans had intelligence, they were still bound by the rules of nature. So that most of Ar-Rohmah Senior High School students had an understanding that beside humans had intelligence and abilities, but were also limited by the rules of nature. This means that when humans could cultivated nature, humans must also defend the environment's rights to be kept in balance. This was following the opinion of Taufiq (2016) that the harmony of life between humans and the environment can be maintained properly if there was awareness from humans themselves as leaders on earth to protect and care for the environment as a place where humans were located. The mean percentage value on item 10 is $23 \%$. This means that more than half of the respondents did not agree that the issue of environmental damage currently facing the community was being exaggerated. So that most of the students of Ar-Rohmah Senior High School had an understanding that the environmental damage that was currently being faced indeed did not an exaggerated issue. It was following the opinion from Munir (2016) that environmental problems were no longer a problem of a nation and country, but the whole world was faced with very complex environmental problems. This means that environmental problems that were currently occurring did not just issues but real things that have happened. It was also confirmed by opinion from Chaerina (2016) that the destruction of nature was a real issue that occured around us.

The mean percentage value on item 11 is $43 \%$. This means that more than half of the respondents did not agree that the earth was likened to an outer plant that has limited resources and space. So that most of the students of Ar-Rohmah Senior High School had an understanding that the earth has unlimited natural resources and wide space. This contradicts opinion from Hidayat (2011) that natural resources owned by the earth should not be exploited continuously because not all natural resources were renewable (renewable). The mean percentage score on item 12 was $91 \%$. This means that almost all of the respondents agreed that humans were destined to rule all of nature. So that most of the students of Ar-Rohmah Senior High School had an understanding that humans were created to control all of nature. It was contrary to the theory of environmental science put forward byMiller, G.T, and Spollman (2016) that humans were part of nature and must maintain harmonious interactions, not dominated nature to create a sustainable environment.

The mean percentage value on item 13 is $62 \%$. This means that more than half of the respondents agreed that the natural balance was very easily disturbed. So that most students of Ar-Rohmah Senior High School had an understanding that the balance of nature was easily disturbed by human activities. The mean percentage value on item 14 is $72 \%$. This means that more than half of the respondents agreed that humans would learn how nature works so that humans can control it. So that most students of Ar-Rohmah Senior High School had an understanding that humans would learn how to take advantage of nature. according to the opinion from Taufiq (2016) that the harmony of life between humans and the environment can be maintained properly if there was awareness from humans themselves as leaders on earth to protect and care for the environment as a place where humans were located. According to Kahn and Haluza-DeLay (2002), one of the foundations of ecological justice in religion (Al-Qur'an) explains that the task of humans on earth became a 
caliph, one of which was to guard the earth. Humans were equipped with reason and thoughts so that with these 2 things it hoped that humans would be able to protect the earth wisely and responsibly. The mean percentage value on item 15 is 91\%. This means that almost all respondents agreed that if the damaged occurs continuously, the earth would experienced an ecological disaster in a short time. So that most of the students of Ar-Rohmah Senior High School had an understanding that if environmental damage continued, the earth would experience a major ecological disaster. It was following the opinion concerned (2020) that environmental damage that occurs on an ongoing basis will had implications for natural disasters. For example, if the riverbank environment was damaged and did not immediately restored, it would caused flash floods.

Based on the findings above, the material captured by the students of ArRohmah Senior High School Malang from the learning process had not been understood holistically or thoroughly. Especially in the material balance of the ecosystem, the right of natural resources not to be exploited continuously, and the obligation of humans to protect the environment and cultivate it wisely. Therefore the role of the teacher was needed in providing a review of the material in the material section above. So that knowledge about the environment obtained by students perfectly so that they can have a good environmental care attitude.

\section{CONCLUSION}

From the results of the explanation regarding the exploration of environmental awareness among students of the Ar-Rohmah Malang Islamic Boarding School based on the New Ecological Paradigm (NEP) instrument, it can be concluded that in general, students of Ar-Rohmah Senior High School Malang tend to care for the environment / pro-environmental. Class differences indicate a difference in the percentage of caring attitudes towards the environment. When viewed in each item, based on the percentage of responses to the NEP instrument of AR-Rohmah Malang students, it is not understood holistically on several materials such as a balance of the ecosystem, the right of natural resources not to be exploited continuously, and the obligation of humans to protect the environment and cultivate it wisely.

\section{RECOMMENDATION}

With this research, then the role of the teacher is needed in providing a review of the material in the material sub-chapter above, for the sake of the perfection of the knowledge obtained by the students so that it can reflect a caring attitude towards the environment as a whole.

\section{ACKNOWLEDGMENT}

This research is part of an umbrella research funded by the Blockgrant program in 2020 of Faculty of Teacher Training and Education Universitas Muhammadiyah Malang. We would like to thank the Dean of Faculty of Teacher Training and Education Universitas Muhammadiyah Malang.

\section{REFERENCES}

Adack, J. (2013). Dampak pencemaran limbah pabrik tahu terhadap lingkungan hidup. Lex Administratum, 1(3).

Amini, R \& Munandar, A. (2010). Pengaruh model pembelajaran pendidikan lingkungan berbasis outdoor terhadap penguasaan konsep pendidikan 
lingkungan bagi calon guru sekolah dasar. Jurnal Penelitian Pendidikan, 11(1), 1421.

Anggraini, A., Hartuti, P., \& Sholihah, A. (2018). Hubungan pola asuh orang tua dengan kepribadian siswa SMA di Kota Bengkulu. Consilia: Jurnal Ilmiah Bimbingan Dan Konseling, 1(1), 10-18.

Apriliani, T. (2019). Analisis literasi lingkungan siswa smp negeri pada sekolah adiwiyata dan non-adiwiyata se-Tangerang Selatan (Skripsi). Universitas Islam Negeri Syarif Hidayatullah.

Ar-Rohmah Putri, T. (2019). Ar-Rohmah Putri Hidayatullah Malang. Retrieved from www.arrohmahputri.sch.id

Budiningsih, C. A. (2015). Karakteristik siswa sebagai pijakan dalam penelitian dan metode pembelajaran. Jurnal Cakrawala Pendidikan, 1(1), 160-173.

Chaerina, Y. (2016). Korespondensi antara kerusakan ekologi dan faktor penyebabnya. Proceeding Temu Ilmiah IPLBI, 17-22.

Desfandi, M. (2015). Mewujudkan Masyarakat Berkarakter Peduli Lingkungan Melalui Program Adiwiyata. SOSIO DIDAKTIKA: Social Science Education Journal, 2(1), 31-37.

Dunlap, R. E., Van Liere, K. D., Mertig, A. G., \& Jones, R. E. (2000). New Trends in Measuring Environmental Attitudes: Measuring Endorsement of the New Ecological Paradigm: A Revised NEP Scale. Journal of Social Issues, 56(3), 425442.

Dunlap, R., \& Van Liere, K. (1978). The “new environmental paradigm." Journal of Environmental Education, 9(1), 19-28.

Elvazia, H. A. (2017). Perbandingan literasi lingkungan dan sikap peduli lingkungan siswa sekolah adiwiyata dengan siswa sekolah non adiwiyata di Kabupaten Pringsewu (Skripsi). Universitas Lampung.

Farwati, R., Permanasari, A., Firman, H., \& Suhery, T. (2018). Integrasi Problem Based Learning dalam STEM education berorientasi pada aktualisasi literasi lingkungan dan kreativitas. Seminar Nasional Pendidikan IPA, 1(1), 198-206.

Hidayat. (2011). Pengelolaan sumber daya alam berbasis kelembagaan lokal. Citra Lekha, 0(1), 19-31.

Hidayat, A. (2015). Pendidikan islam dan lingkungan hidup. Jurnal Pendidikan Islam, $4(2), 373$.

Ibda, F. (2015). Perkembangan kognitif: teori jean piaget. Intelektualita, 3(1), 242904.

Kahn, P. H., \& Haluza-DeLay, R. (2002). The human relationship with nature. Electronic Green Journal, 3(17).

Komariah, N., M. Yusup, P., Saepudin, E., \& Rodiah, S. (2017). Pendidikan literasi lingkungan sebagai penunjang desa wisata agro Kecamatan Padaherang Kabupaten Pangandaran. Jurnal Aplikasi Ipteks Untuk Masyarakat, 6(2), 111-115.

Kusumaningrum, D. (2018). Literasi Lingkungan Dalam Kurikulum 2013 Dan Pembelajaran Ipa Di Sd. Indonesian Journal of Natural Science Education (IJNSE), 1(2), 57-64.

Lawton, S. (2016). Linking the new ecological paradigm scale to how pro-environmental behavior is developed (Skripsi). University of Nebraska-Lincoln.

Liuw, Y. (2015). Perlindungan hukum terhadap hewan lindung menurut undangundang nomor 5 tahun 1990. Lex Crime, IV(3), 24-29.

Maknun, D. (2011). Praktikum proyek ekologi berbasis kondisi ekobiologis lokal dalam meningkatkan literasi lingkungan dan tindakan konservasi mahasiswa. 
Jurnal Holistik, 12(2), 1-40.

Martini. (2019). Hubungan antara pengetahuan lingkungan dengan perilaku prolingkungan sekolah adiwiyata (Studi kasus SDn 21 Taluak Kab. Agam). Rang Teknik Journal, 2(1), 71-78.

McBeth, W., \& Volk, T. (2010). The national environmental literacy project: A baseline study of middle grade students in the United States. Journal of Environmental Education, 41(1), 55-67.

Miles, M. B. \& A. . H. (1992). Analisis data kualitatif: buku sumber tentang metode-metode baru. Jakarta. UI Press.

Miller, G. T \& Spollman, S. E. (2016). Living in the environmental. Buston. Cengage Learning.

Muhith, A. (2019). Pembelajaran literasi membaca di pondok pesantren Sidogiri Kraton Pasuruan dinyatakan asosiasi internasional untuk evaluasi prestasi (international association for the evaluation of educational achievement ) dalam progress in international reading literac. Journal of Islamic Education Research, $1(01)$.

Mullis, I. V. S., Martin, M. O., Foy, P., \& Drucker, K. T. (2012). PIRLS 2011 International Results in Reading. Amsterdam. In TIMSS \& PIRLS International Study Center.

Mulyana, R. (2009). Penanaman etika lingkungan melalui sekolah peduli dan berbudaya lingkungan. Jurnal Tabularasa PPS Unimed, 6(2), 175-180.

Munir, M. (2016). Prinsip biologi dalam lingkungan berkelanjutan. Al-Ard: Jurnal Teknik Lingkungan, 2(1), 31-37.

Nasution, R. (2016). Analisis kemampuan literasi lingkungan siswa SMA kelas X di Samboja dalam pembelajaran biologi. Proceeding Biology Education Conference, ISSN: 2528-5742, pp. 352-358.

Nisa, Z. K. (2019). Pengembangan pendidikan lingkungan hidup di pondok pesantren kabupaten Blitar. Briliant: Jurnal Riset Dan Konseptual, 4(1), 105.

Nugroho, W. A., Karyanto, P., \& Nurmiyati. (2016). Pengembangan subject specific pedagogy berbasis problem based learning untuk penguatan sikap peduli lingkungan siswa kelas VII SMP. BIO-PEDAGOGI, 5(2), 31-42.

Prihatin, R. B. (2020). Banjir dan rusaknya ekologi perkotaan. Puslit Badan Keahlian DPR RI, 9(1), 13.

Pujianti, N. (2018). Analisis kemampuan literasi lingkungan siswa SMP dalam pembelajaran pencemaran lingkungan dengan menggunakan problem based learning di daerah pertanian dan pesisir Subang (Skripsi). Universitas Pendidikan Indonesia.

Puspita, I., Ibrahim, L., \& Hartono, D. (2016). Pengaruh perilaku masyaraka yang bermukim di kawasan bantaran sungai terhadap penurunan kualitas air sungai Karang Anyar Kota Tarakan (Influence of the behavior of citizens residing in riverbanks to the decrease of water quality in the river of karang). Jurnal Manusia Dan Lingkungan, 23(2), 249.

Saputro, K. Z. (2018). Memahami ciri dan tugas perkembangan masa remaja. Aplikasia: Jurnal Aplikasi Ilmu-Ilmu Agama, 17(1), 25.

Subramanian, K. R. (2018). The crisis of consumption of natural resources. International Journal of Recent Innovations in Academic Research (IJRIAR, 2(4).

Sukwika, T., Darusman, D., Kusmana, C., \& Nurrochmat, D. R. (2018). Skenario kebijakan pengelolaan hutan rakyat berkelanjutan di Kabupaten Bogor. Jurnal Pengelolaan Sumberdaya Alam Dan Lingkungan (Journal of Natural Resources and 
Environmental Management), 8(2), 207-215.

Syafe'i, I. (2015). PONDOK PESANTREN: lembaga pendidikan pembentukan karakter. Al-Tadzkiyyah: Jurnal Pendidikan Islam, 8(1), 85-103.

Taufiq, A. (2016). Upaya pemeliharaan lingkungan oleh masyarakat di Kampung Sukadaya Kabupaten Subang. Jurnal Geografi Gea, 14(2), 124-134.

Utama, R. N. P. W. (2020). Analisis literasi lingkungan pada sma thailand selatan (studi kasus di mathayom sangkhom islam wittaya school) (Skripsi). Universitas Muhammadiyah Malang.

Widianingsih, W. M., Karyanto, P., Prayitno, B. A., \& Irawati, M. (2017). Environmental learning through development of subject specific pedagogy based on problem based learning to reinforce student's environmental literacy in grade X MIA senior high school. Proceeding Biology Education Conference, 14(1), 441-448.

Zulfa, V., Max, M., Hukum, I., \& Ilyas, I. (2015). Isu-Isu Kritis Lingkungan Dan Perspektif Global. Jurnal Green Growth Dan Manajemen Lingkungan, 5(1), 29-40. 